\title{
Chemical Composition and Antimicrobial Activity of Fresh Rhizome Essential Oil of Zingiber Officinale Roscoe
}

\author{
Pradeep Kumar Sharma ${ }^{1 *}$, Vijender Singh ${ }^{2}$, Mohammed $\mathrm{Ali}^{3}$ \\ 'Department of Pharmacy, R V Northland Institute, Greater Noida, G B Nagar, U.P. 203207, INDIA. \\ 2B B S College of Pharmacy, Greater Noida, G B Nagar, U.P. 201306, INDIA. \\ 3Phytochemistry Research Laboratory, Faculty of Pharmacy, Jamia Hamdard, Hamdard Nagar, New Delhi 110062, INDIA.
}

\begin{abstract}
Background: Zingiber officinale Roscoe (Zingiberaceae) is a rhizomatous perennial herb found in tropical Asia. It is extensively used worldwide as a spice, flavoring agent and herbal remedy for cold, throat and chest infections and cough. The present study was carried out to analyse an essential oil from the fresh rhizomes of $Z$. officinale of Ghaziabad region and to evaluate its antimicrobial activity. Materials and Methods: The fresh rhizomes were hydrodistilled to get the essential oil which was analysed by GC and GC-MS techniques. The oil was evaluated for antimicrobial activity by disc diffusion method. Results and Discussion: The essential oil was characterized by high percentage of sesquiterpenes $(66.66 \%)$, monoterpenes $(17.28 \%)$ and aliphatic compounds (13.58\%). The predominant sesquiterpene was zingiberene $(46.71 \%)$ followed by valencene $(7.61 \%)$, $\beta$-funebrene $(3.09 \%)$ and selina-4(14),7(11)-diene (1.03\%). The major monoterpenes were characterized as citronellyl $n$-butyrate (19.34\%), $\beta$-phellandrene (3.70\%), camphene $(2.59 \%)$ and $\alpha$-pinene (1.09\%). The essential oil exhibited significant antimi-
\end{abstract}

crobial activity against Bacillus subtilis, Staphylococcus aureus, Escherichia coli, Pseudomonas aeruginosa, Candida albicans and Aspergillus niger. Conclusion: The essential oil mainly contained a large number of sesquiterpenes and monoterpenes and exhibited significant antimicrobial activity against pathogenic microorganisms.

Key words: Antimicrobial activity, Chemical composition, Essential oil, GC-MS analysis, Zingiber officinale.

Correspondence:

Pradeep Kumar Sharma,

Department of Pharmacy, R V Northland Institute, Greater Noida,

G B Nagar, U.P. 203207, INDIA.

Phone no: 9711360405

Email: pradeepbsr2000@yahoo.com

DOI : $10.5530 /$ pj.2016.3.3

\section{INTRODUCTION}

Zingiber officinale Roscoe (Zingiberaceae) known as adrak or ginger, is an important plant with several ethnomedicinal and nutritional uses. It is a rhizomatous perennial herb reaching up to $90 \mathrm{~cm}$ in height. The rhizomes are aromatic, thick lobed, white to yellowish-brown, irregularly branched, annulated and compressed with smooth surface. ${ }^{1,2}$ It is originally found in tropical Asia and now cultivated as a commercial crop in India, China, Australia, America, Africa as well as South East Asia. ${ }^{3-5}$ Ginger is cultivated in tropical and subtropical regions. It is grown by vegetative means. Ginger is planted during April-May and harvested about 7-8 months (December-January) after planting when the leaves turn yellow and gradually wither. Harvesting is done by digging the rhizomes. They are washed properly and then dried to improve the colour. ${ }^{6}$ It is extensively utilized worldwide as a spice, flavoring agent and herbal remedy. In different traditional systems it is taken to cure a variety of diseases such as nausea, vomiting, asthma, palpitation, inflammation, dyspepsia, loss of appetite, constipation, digestion and pain. ${ }^{7,8}$

Ginger contains $1-2 \%$ of essential oil, which imparts the unique flavor to the spice and it has been studied by many workers. ${ }^{8-13}$ Many reports are available on the chemical composition of fresh ginger oil and the naturally occurring flavoring compounds. ${ }^{14-16}$ Various reports are available on the antimicrobial property of the essential oil from the rhizomes of ginger. ${ }^{17-24}$ The essential oils are the reservoir of biologically active compounds and there has been increased interest in looking at their antimicrobial properties. ${ }^{25}$ The major pungent compounds of fresh ginger are active gingerols which are a homologous of phenols. The most abundant is 6-gingerol. The pungency of dry ginger is mainly due to the presence of shogaols which are dehydrated forms of gingerols. ${ }^{26}$ The ginger oil contains a mixture of constituents such as monoterpenes, namely phellandrene, camphene, cineole, linalool, limonene, citral, geraniol, citronellol, borneol and sesquiterpenes, namely $\alpha$-zingiberene, ar-curcumene, $\beta$-bisabolene, $\beta$-sesquiphellandrene, zingiberol and zingiberenol along with some aliphatic aldehydes and alcohols. ${ }^{27-40}$ The composition of volatile oil is highly variable depending upon a variety of factors including their geographical origin, distillation procedures, post harvest treatment, processing, drying conditions and temperature. ${ }^{41-43}$ In the present communication, we report essential oil composition of the rhizomes of $Z$. officinale from Ghaziabad region and its antimicrobial activity.

\section{MATERIALS AND METHODS}

Plant material

The fresh rhizomes of $Z$. officinale were purchased from the local market of Ghaziabad. The plant material was identified and authenticated by Dr. K C Bhatt, National Bureau of Plant Genetic Resources, Pusa Campus, New Delhi. A specimen sample was deposited in the herbarium division of our Institute.

\section{Preparation of plant material}

Fresh rhizomes of the plant Z. officinale were collected and washed thoroughly under running tap water to remove adhered soil and foreign matter. The rhizomes were cut into small pieces and pulverized to course powder using a mechanical grinder and the powder was preserved in air sealed polyethene bag.

\section{Isolation of the essential oil}

The fresh rhizomes ( $1 \mathrm{~kg}$ ) of $Z$. officinale were hydrodistilled in Clevenger type glass apparatus for $4 \mathrm{~h}$. The essential oil was collected, measured and dried over anhydrous sodium sulphate and stored at $4^{\circ} \mathrm{C}$ in the dark. This oil was used for GC, GC-MS and evaluation of antimicrobial activity. The yield of essential oil obtained from the fresh ginger was $1.26 \%$.

\section{GC Analysis}

The gas chromatographic analysis of the essential oil was carried out on a GC-2010 (Shimadzu) equipped with a flame ionization detector (FID) 
and ULBON HR-1 fused silica capillary column $(60 \mathrm{~m} \times 0.25 \mathrm{~mm} \times 0.25 \mu \mathrm{m})$. The injector and detector (FID) temperatures were maintain at 250 and $270^{\circ} \mathrm{C}$, respectively. The carrier gas used was nitrogen at a flow rate of $1.21 \mathrm{ml} / \mathrm{min}$ with column pressure of $155.1 \mathrm{kPa}$. The sample $(0.2 \mu \mathrm{l})$ was injected into the column with a split ratio of 80:1. Component separation was achieved following a linear temperature programmed from 60 to $230^{\circ} \mathrm{C}$ at a rate of $3^{\circ} \mathrm{C} / \mathrm{min}$ and then held at $230^{\circ} \mathrm{C}$ for $9 \mathrm{~min}$, with a total run time of $55.14 \mathrm{~min}$. Percentage of the constituents were calculated by electronic integration of FID peak areas.

\section{GC-MS Analysis}

The GC-MS analysis was carried out on a GC-MS-QP 2010 Plus (Shimadzu) fitted with a Column AB-Innowax ( $60 \mathrm{~m} \times 0.25 \mathrm{~mm}$ i.d., film thickness $0.25 \mu \mathrm{m}$ ), The carrier gas was nitrogen at a flow rate $1.21 \mathrm{ml} / \mathrm{min}$. The oven column temperature was initially kept at $60^{\circ} \mathrm{C}$ for $10 \mathrm{~min}$ and increased up to $230^{\circ} \mathrm{C}$ at a rate of $4^{\circ} \mathrm{C} / \mathrm{min}$, then held at $230^{\circ} \mathrm{C}$ for $10 \mathrm{~min}$ and increased up to $260^{\circ} \mathrm{C}$ at a rate of $1^{\circ} \mathrm{C} / \mathrm{min}$ and then held at $260^{\circ} \mathrm{C}$ for $10 \mathrm{~min}$. The split flow was $101 \mathrm{ml} / \mathrm{min}$. The split ratio was $1: 80$. The injector temperature was $240^{\circ} \mathrm{C}$ and detector temperature was $280^{\circ} \mathrm{C}$. Injection volume was $0.3 \mu \mathrm{l}$. The ionization energy (voltage) was $70 \mathrm{eV}$ and mass scan range $(\mathrm{m} / \mathrm{z})$ was $40-850 \mathrm{amu}$. The percentage composition of the oil was calculated automatically from the FID peak area without any correction.

\section{Identification of compounds}

The individual compounds were identified by comparing their Kovat's indices (KI) of the peaks on Innowax fused silica capillary column with literature values, matching against the standard library spectra, built up using pure substances and components of known essential oils. Further identification was carried out by comparison of fragmentation pattern of the mass spectra obtained by GC-MS analysis with those stored in the spectrometer database of NBS $54 \mathrm{~K} \mathrm{~L}$, WILEY 8 libraries and published literature (Adams et al., 2001; Ali 2001; Joulain and Konig 1998; McLafferty 1994). Relative amounts of identical components were based on peak areas obtained without FID response factor correction.

\section{Antimicrobial activity \\ Study design:}

Test microorganisms or isolates

Microorganisms selected for the study were Bacillus subtilis (MTCC 441), Staphylococcus aureus (MTCC 737), Escherichia coli (MTCC 443), Pseudomonas aeruginosa (MTCC 424) and fungi species namely Candida albicans (MTCC 227), Aspergillus niger (MTCC 404). All the test strains were obtained from the Institute of Microbial Technology (IMTECH), Chandigarh, India. All strains were maintained at $4^{\circ} \mathrm{C}$ over nutrient agar slants throughout the experiment and used as stock cultures.

\section{Media}

Nutrient agar media was composed of beef extract $(1.0 \mathrm{~g})$, yeast extract ( $2.0 \mathrm{~g})$, peptone $(5.0 \mathrm{~g})$, sodium chloride $(5.0 \mathrm{~g})$, agar $(15.0 \mathrm{~g})$ and distilled water $(1.0 \mathrm{~L})$.

Sabouraud dextrose agar media was composed of dextrose $(40.0 \mathrm{~g})$, mycological peptone $(10.0 \mathrm{~g})$, agar $(15.0 \mathrm{~g})$ and distilled water $(1.0 \mathrm{~L})$.

\section{Preparation of media}

Nutrient agar medium ( $28 \mathrm{~g}$ ) was accurately weighed, suspended in 1000 $\mathrm{ml}$ of distilled water in a conical flask and heated to boiling to dissolve the medium completely. The conical flask containing the nutrient agar medium was plugged with a non-absorbent cotton plug and covered properly with an aluminum foil. It was sterilized by autoclaving at 15 -lbs/in ${ }^{2}$ pressure $\left(121^{\circ} \mathrm{C}\right)$ for $15 \mathrm{~min}$. Sabouraud dextrose agar medium $(65 \mathrm{~g})$ was accurately weighed, suspended in $1000 \mathrm{ml}$ of distilled water in a conical flask and heated to boiling to dissolve the medium completely. The conical flask containing the sabouraud dextrose agar medium was plugged with a non-absorbent cotton plug and covered properly with an aluminum foil. It was sterilized by autoclaving at $15-\mathrm{lbs} / \mathrm{in}^{2}$ pressure $\left(121^{\circ} \mathrm{C}\right)$ for $15 \mathrm{~min}$.

\section{Preparation of organisms or inoculums}

The test organisms were maintained on freshly prepared medium slants. The slants were incubated at $37^{\circ} \mathrm{C}$ for $24 \mathrm{~h}$. The organisms from the medium slants were washed using $3 \mathrm{ml}$ of saline solution and incubated for $24 \mathrm{~h}$ at $37 \pm 2^{\circ} \mathrm{C}$. The developed organisms from the nutrient media were washed using $50 \mathrm{ml}$ of distilled water. A dilution factor was determined which gave $25 \%$ light transmission at $530 \mathrm{~nm}$. The amount of suspension to be added to each $100 \mathrm{ml}$ nutrient broth was determined by use of test plates or test broth. The test organisms were stored under refrigeration.

\section{McFarland turbidity standard}

A McFarland standard No. 0.5 was used for quality control. It was prepared by adding $0.5 \mathrm{ml}$ of a $1.175 \%(\mathrm{w} / \mathrm{v})$ barium chloride dihydrate $\left(\mathrm{BaCl}_{2} \cdot 2 \mathrm{H}_{2} \mathrm{O}\right)$ solution to $99.5 \mathrm{ml}$ of $1 \%(\mathrm{v} / \mathrm{v})$ sulphuric acid.

\section{Antimicrobial standard}

The stock solution of $100 \mu \mathrm{g} / \mathrm{ml}$ of Tetracycline and Fluconazole were prepared by adding $10 \mathrm{mg}$ of drug in $100 \mathrm{ml}$ of dimethyl sulphoxide (DMSO). The further $10 \mu \mathrm{g} / \mathrm{ml}$ of Tetracycline and Fluconazole were obtained by diluting $1 \mathrm{ml}$ of stock solution upto $10 \mathrm{ml}$ of dimethyl sulphoxide (DMSO).

\section{Test procedure}

\section{Susceptibility testing by disc diffusion method:}

\section{Determination of Zone of inhibition (ZOI)}

A standard disc diffusion method by Baurer et al. (1966) ${ }^{44}$ was used. The antimicrobial activity of essential oil was investigated by disc diffusion method in triplicate using 24-48 h grown strains reseeded on nutrient media. The cultures were adjusted with saline water to obtain a suspension at concentration of $1 \times 10^{6} \mathrm{CFU} / \mathrm{ml}$ with a McFarland standard No. 0.5 , then $100 \mu \mathrm{l}$ of the suspension was spread on nutrient agar media plates to obtain uniform microbial growth. Sterile filter paper discs (Whatman's No. $5,6 \mathrm{~mm}$ in diameter) were impregnated with $10 \mu \mathrm{l}$ of the essential oil and placed on the surface of the agar test plate. Control discs were saturated with Tetracycline $(10 \mu \mathrm{g} / \mathrm{disc})$. Plates were subsequently incubated at $37^{\circ} \mathrm{C}$ for $24 \mathrm{~h}$. The zones of inhibition were calculated by measuring the diameter in $\mathrm{mm}$.

In the case of fungi, the test was performed in sterile petri dishes containing sabouraud dextrose agar (SDA). The oil was adsorbed on sterile paper disc and placed on the surface of the medium previously inoculated with a suspension of fungus. Control discs were saturated with Fluconazole $(10 \mu \mathrm{g} / \mathrm{disc})$. All petri dishes were sealed with a sterile laboratory film to avoid evaporation of the test samples and incubated at $27^{\circ} \mathrm{C}$ for $48 \mathrm{~h}$. The zone of inhibition was determined by measuring the diameter in $\mathrm{mm}$ of the clear zone around each disc.

\section{Determination of minimum inhibitory concentration (MIC)}

The minimal inhibitory concentration (MIC) was determined as described by Daw et al. (1994). ${ }^{45}$ The MIC was defined as the lowest concentration of tested samples showing no visible bacterial growth after $24 \mathrm{~h}$ incubation period at $37^{\circ} \mathrm{C}$. Disc diffusion method was used for determination of MIC in triplicate. Petri dishes contained $15 \mathrm{ml}$ of nutrient agar for bacteria and sabouraud dextrose agar (SDA) for fungi, supplemented by test strains at a density of $1 \times 10^{6} \mathrm{CFU} / \mathrm{ml}$. Four discs $(6.0 \mathrm{~mm}$ in diameter) were made in each agar plate. The essential oil 
was dissolved in dimethyl sulphoxide (DMSO) in two-fold serial dilutions were made in concentration range from $10 \mu \mathrm{l} / \mathrm{ml}$ to $1 \mu \mathrm{l} / \mathrm{ml}$. DMSO blank was used as negative control. The plates of bacteria were incubated at $37^{\circ} \mathrm{C}$ for $24 \mathrm{~h}$ and plates of fungi were incubated at $27^{\circ} \mathrm{C}$ for $48 \mathrm{~h}$. The least concentration of the essential oil showing a clear of inhibition was taken as the MIC.

\section{Statistical analysis}

Tests were carried out in triplicate and the results were calculated as standard means $( \pm S D)$. Difference on statistical analysis of data were considered significant at $\mathrm{P}<0.05$.

\section{RESULTS AND DISCUSSION}

The chemical constituents of the essential oil were identified by analysis of GC and GC-MS. The chemical composition of ginger oil is tabulated in Table 1 with their Kovat's indices and respective percentage. The essential oil was characterized by high percentage of sesquiterpenes $(66.66 \%)$, monoterpenes (17.28\%) and aliphatic compounds (13.58\%). In the essential oil eighty compounds were identified among which zingiberene (46.71\%) was the major component followed by citronellyl $n$-butyrate (19.34\%), valencene (7.61\%) and $\beta$-phellandrene (3.70\%). Among the 52 sesquiterpenes $(66.66 \%)$, the major ones were zingiberene $(46.71 \%)$, valencene (7.61\%), $\beta$-funebrene (3.09\%) and selina-4(14), 7(11)-diene (1.03\%). The other remaining sesquiterpenes were present in less than one percent. Among 14 monoterpenes, there were eight monoterpene hydrocarbons (9.87\%), two monoterpene ketones $(2.46 \%)$ and four monoterpene esters $(4.93 \%)$. The predominant monoterpenes were citronellyl $n$-butyrate (19.34\%), $\beta$-phellandrene (3.70\%), camphene (2.59\%) and $\alpha$-pinene (1.09\%). The other monoterpenes were detected in less than one per cent. A total 11 aliphatic constituents were characterized in the essential oil. Methyl eugenol was the only aromatic component present in the oil. The other components present in the essential oil included $\alpha$-agarofuran and ledene oxide.

Various studies have shown that ginger oils are very complex mixtures of compounds and many variations have been found in the chemical composition, geranial $(25.9 \%)$ as the major constituent in ginger oil. ${ }^{46}$ Zingiberene and $\beta$-sesquiterpene were the main components in the range of 10 to 60 percent. ${ }^{47}$ The main constituents of Sikkim ginger oil were geranyl acetate $(18.8 \%)$, zingiberene $(16.3 \%)$ and geranial $(8.2 \%){ }^{48}$ The main components of Nigerian ginger oil were zingiberene (29.5\%) and sesquiphellandrene (18.4\%). ${ }^{49}$ Ar-curcumene (11\%), $\beta$-bisabolene (7.2\%), sesquiphellandrene $(6.6 \%)$ and $\delta$-cadinene (3.5\%) were the prominent constituents of dry ginger oil of Nedumangadu variety from Trivendrum (Kerala). ${ }^{37} \mathrm{a}$-Zingiberene (15.92\%), geraniol (11.75), bisabolene (11.12\%), neral (9.25\%), $\beta$-phellandrene (7.73\%) and $\beta$-sesquiphellandrene (5.26\%) were the main components of the rhizome oil of Zingiber officinale from Pantnagar (Uttarakhand).$^{50}$ Such variations in the chemical composition of distilled oils were recorded not only due to the existence of different species but also might be attributed to the different agro-climatic conditions like climatic conditions, regions, stage of maturity, harvesting time of plants and distillation conditions. $^{46,51}$

The antimicrobial activity of volatile oil was tested against Bacillus subtilis, Staphylococcus aureus, Escherichia coli, Pseudomonas aeruginosa, Candida albicans and Aspergillus niger. As shown in Table 2, the volatile oil showed significant antimicrobial activities in comparison to the standards, Tetracycline and Fluconazole. The zones of inhibition were in the range of 10.4 to $12.5 \mathrm{~mm}$ and 8.3 to $12.5 \mathrm{~mm}$ for bacterial and fungal strains, respectively. The standard, Tetracycline had a 10.0 to $15.0 \mathrm{~mm}$ zone of inhibition in case of bacterial strains. The standard, Fluconazole had a 8.2 to $12.2 \mathrm{~mm}$ zone of inhibition in case of fungal strains. A strong
Table 1: Chemical composition of the essential oil of the fresh rhizomes of Zingiber officinale from Ghaziabad region

\begin{tabular}{|c|c|c|}
\hline Components & Kovat's Index & $\%$ Area \\
\hline a-Pinene & 937 & 1.09 \\
\hline Camphene & 943 & 2.53 \\
\hline 2-Methyl nonane & 964 & 0.29 \\
\hline Myrcene & 975 & 0.45 \\
\hline a-Phellandrene & 987 & 0.20 \\
\hline 3-Octen-2-one & 1006 & 0.63 \\
\hline$(+)$-a-Limonene & 1011 & 0.82 \\
\hline$\beta$-Phellandrene & 1015 & 3.70 \\
\hline a-Terpinolene & 1067 & 0.16 \\
\hline n-Nonenal & 1130 & 0.14 \\
\hline 2-Methyl undecane & 1164 & 0.15 \\
\hline 3-Methyl butanol & 1205 & 0.54 \\
\hline n-Nonan-2-one & 1280 & 0.11 \\
\hline a-Nagniatene & 1317 & 0.18 \\
\hline a-Cubebene & 1348 & 0.16 \\
\hline$\delta$-Elemene & 1345 & 0.53 \\
\hline p-Menth-1-en-8-ol acetate & 1348 & 0.11 \\
\hline Cyclosativene & 1357 & 0.55 \\
\hline a-Copaene & 1375 & 0.95 \\
\hline n-Undecanol & 1381 & 0.37 \\
\hline Geranyl acetate & 1383 & 0.32 \\
\hline Camphor isomer & 1391 & 0.10 \\
\hline Methyl eugenol & 1404 & 0.68 \\
\hline Bergamotene & 1417 & 0.95 \\
\hline a-Santalene & 1419 & 0.54 \\
\hline Geranyl propionate & 1430 & 0.25 \\
\hline (Z,E)-a-Farnesene & 1433 & 0.10 \\
\hline$\gamma$-Elemene & 1437 & 0.41 \\
\hline n-Decanyl acetate & 1439 & 0.39 \\
\hline Neryl acetone & 1441 & 0.79 \\
\hline Allo-Aromadendrene & 1455 & 0.32 \\
\hline Germacrene D & 1458 & 0.82 \\
\hline$\beta$-Funebrene & 1473 & 3.09 \\
\hline Zingiberene & 1490 & 46.71 \\
\hline Valencene & 1492 & 7.61 \\
\hline Selina-4(14), 7(11)-diene & 1495 & 1.03 \\
\hline Citronellyl n-butyrate & 1501 & 19.34 \\
\hline a-Muurolene & 1503 & 0.10 \\
\hline Cuparene & 1505 & 0.38 \\
\hline a-Bisabolene & 1507 & 0.05 \\
\hline$\beta$-Bisabolene & 1513 & 0.15 \\
\hline$\gamma$-Cadinene & 1515 & 0.06 \\
\hline$\beta$-Curcumene & 1516 & 0.04 \\
\hline
\end{tabular}




\begin{tabular}{|c|c|c|}
\hline Components & Kovat's Index & $\%$ Area \\
\hline$\delta$-Cadinene & 1518 & 0.10 \\
\hline Myristicin & 1519 & 0.14 \\
\hline$\alpha$-Cubebene & 1522 & 0.43 \\
\hline$\beta$-Sesquiphellandrene & 1525 & 0.06 \\
\hline trans-Calamenene & 1529 & 0.04 \\
\hline cis-Cadina-1, 4-diene & 1535 & 0.31 \\
\hline Selina-3,7-diene & 1542 & 0.10 \\
\hline a-Agarofuran & 1546 & 0.41 \\
\hline Sesquisabinene hydrate & 1548 & 0.12 \\
\hline Epiglobulol & 1551 & 0.76 \\
\hline 2-Pentadecen-4-yne & 1555 & 0.24 \\
\hline $\begin{array}{c}\text { 4-(2,6,6 -Trimethyl-2-cyclohexen-1-ylidene) } \\
\text {-2- butanone }\end{array}$ & 1557 & 0.11 \\
\hline (E)-Nerolidol & 1558 & 0.06 \\
\hline Caryophyllene alcohol & 1560 & 0.03 \\
\hline Globulol & 1584 & 0.34 \\
\hline 10-Epi- $\gamma$-Eudesmol & 1597 & 0.33 \\
\hline Zingiberenol & 1601 & 0.86 \\
\hline (-) Globulol & 1604 & 0.19 \\
\hline $\begin{array}{c}\text { 1,5,5,8-Tetramethyl -3,7-Cycloundecadien } \\
-1 \text {-ol }\end{array}$ & 1607 & 0.06 \\
\hline Agaruspirol & 1631 & 0.03 \\
\hline$\gamma$-Eudesmol & 1635 & 0.29 \\
\hline Muurolol & 1641 & 0.02 \\
\hline$\beta$-Eudesmol & 1649 & 0.05 \\
\hline$\alpha$-Eudesmol & 1652 & 0.15 \\
\hline Eudesm-4(14) - en-11-ol & 1654 & 0.19 \\
\hline Ledene oxide & 1668 & 0.03 \\
\hline 8-Cedren-13-ol & 1671 & 0.05 \\
\hline $\begin{array}{l}\text { 2,2,5,5-Tetramethyl tricyclo } \\
{[6.3 \cdot 0.0 \cdot(3,7)] \text {-undec-1(8)-en-3-ol }}\end{array}$ & 1683 & 0.01 \\
\hline 3,7,11-Trimethyl-2,10-docecadien-1-ol & 1688 & 0.03 \\
\hline$\alpha$-Bisabolol pentanoate & 1695 & 0.02 \\
\hline (E)-Nuciferol & 1705 & 0.01 \\
\hline Longifolene aldehyde & 1715 & 0.50 \\
\hline Caryophyllic acid & 1731 & 0.03 \\
\hline$\beta$-Bisabolene-12-ol & 1739 & 0.02 \\
\hline $\begin{array}{l}\text { 1,8-Dimethyl-8,9-epoxy-4-isopropyl spiro } \\
\text { (4.5)decan-7-one }\end{array}$ & 1755 & 0.07 \\
\hline Heptadecanoic acid & 1761 & 0.05 \\
\hline$\alpha$-Atlantone & 1773 & 0.00 \\
\hline
\end{tabular}

antibacterial activity against $S$. aureus, P. aeruginosa followed by E. coli which was on par with standard (positive control) and weaker than standard towards B. subtilis. The essential oil also showed strong antifungal activity against $C$. albicans and $A$. niger which was also on par with standard (positive control).
Table 2: Zone of Inhibition ( $\mathrm{mm}$ ) and Minimum inhibitory concentration $(\mu \mathrm{l} / \mathrm{ml})$

\begin{tabular}{ccccc}
\hline Microorganisms & \multicolumn{3}{c}{ ZOI $(\mathrm{mm}) \pm \mathrm{SD}(\mathrm{n}=3)$} & $\begin{array}{c}\text { MIC }(\mu \mathrm{l} / \mathrm{ml}) \\
\pm \mathrm{SD}(\mathrm{n}=3)\end{array}$ \\
\cline { 2 - 5 } & $\begin{array}{c}\text { Ginger } \\
\text { Oil }\end{array}$ & $\begin{array}{c}\text { DMSO } \\
\text { (Negative } \\
\text { Control) }\end{array}$ & $\begin{array}{c}\text { Standard } \\
\text { (Positive } \\
\text { Control) }\end{array}$ & Ginger Oil \\
\hline Gram Positive Bacteria & & & & \\
Bacillus subtilis & $12.5 \pm 0.7$ & No Zone & $15.0 \pm 0.5$ & $10 \pm 0.8$ \\
Staphylococcus aureus & $12.0 \pm 0.2$ & No Zone & $11.5 \pm 0.2$ & $8 \pm 0.7$ \\
Gram Negative Bacteria & & & & \\
Escherichia coli & $10.6 \pm 0.3$ & No Zone & $10.5 \pm 0.2$ & $6 \pm 0.1$ \\
Pseudomonas aeruginosa & $10.4 \pm 0.8$ & No Zone & $10.0 \pm 0.1$ & $5 \pm 0.2$ \\
Fungi & & & & \\
Candida albicans & $12.5 \pm 0.4$ & No Zone & $12.2 \pm 0.1$ & $1 \pm 0.1$ \\
Aspergillus niger & $8.3 \pm 0.3$ & No Zone & $8.2 \pm 0.1$ & $1 \pm 0.3$ \\
\hline
\end{tabular}

ZOI (Zone of inhibition): Ginger oil concentration-10 $\mu \mathrm{l} /$ disc, Negative control -Dimethylsufoxide (DMSO), Standard (Positive control)-Tetracycline-10 $\mu \mathrm{g} / \mathrm{disc}$ for bacteria and Fluconazolae-10 $\mu \mathrm{g} / \mathrm{disc}$ for fungi.

MIC (Minimum inhibitory concentration): Oil concentration range from $1 \mu \mathrm{l} / \mathrm{ml}$ to $10 \mu \mathrm{l} / \mathrm{ml}$.

Previous investigations also reported that ginger essential oils exhibited an inhibitory effect against a wide range of pathogenic bacteria and fungi and their effect was probably due to their major components of oil. The result indicates that there is a relationship between the chemical constituents of oils and its antimicrobial activity. It has also been reported that ginger (rich in sesquiterpenes) essential oils possessed a wide spectrum of antimicrobial activity. ${ }^{46,51,52}$ However, antimicrobial activity (bioactivity) of essential oils was dependent not only on the major components but also on the chemical structures of these components. $^{45,53}$

The antimicrobial activity of oil was assessed by determination of minimum inhibitory concentration. Ginger oil exhibited significant inhibitory effect against all tested organisms with MIC values ranged from 1 to $10 \mu \mathrm{l} / \mathrm{ml}$. As indicated in Table 2, the ginger oil had greater activity towards $C$. albicans and A. niger. The MIC value was higher in case of B. subtilis and weaker in C. albicans and A. niger.

\section{CONCLUSION}

The major components of the essential oil of ginger from Ghaziabad region were zingiberene (46.71\%), citronellyl n-butyrate (19.34\%), valencene (7.61\%) $\beta$-phellandrene (3.70\%), $\beta$-funebrene (3.09\%), camphene $(2.59 \%)$, $\alpha$-pinene (1.09\%) and selina-4(14),7(11)-diene (1.03\%). The essential oil mainly contained a large number of sesquiterpenes $(66.66 \%)$ and monoterpenes (17.28\%). The essential oil showed significant antimicrobial activity against pathogenic microorganisms. The presence of zingiberene in large amount in the essential oil makes it medicinally valuable.

\section{ACKNOWLEDGEMENT}

The authors are grateful to Dr. K C Bhatt, National Bureau of Plant Genetic Resources, Pusa Campus, New Delhi for plant identification and authentication. We are also grateful to Head, AIRF, Jawaharlal Nehru University, New Delhi, for recording GC and GC-MS analysis of the volatile oil.

\section{CONFLICT OF INTEREST}

The author declare no conflict of interest. 
Sharma, Singh and Ali: Chemical composition and antimicrobial activity of fresh rhizome essential oil of Zingiber officinale Roscoe

\section{ABBREVIATION USED}

GC: Gas Chromatography, GC-MS: Gas Chromatography-Mass Spectroscopy, FID: Flame Ionization Detector, KI: Kovat's Index, MTCC: Microbial Type Culture Collection, SDA: Sabouraud Dextrose Agar, DMSO: Dimethyl Sulphoxide, CFU: Colony Forming Unit, ZOI: Zone of Inhibition, MIC: Minimum Inhibitory Concentration.

\section{REFERENCES}

1. Anonymous. Wealth of India, Raw Materials, NISCAIR, CSIR, New Delhi: 2005 Vol. XI, p.89-106.

2. Warrier PK, Nambier VPK, Ramankutty C. Indian medicinal plants, Arya Vaidya Sala, Orient longman Itd. Hyderabad. 1997;5:431-3.

3. Zachariah TA. Ginger. In chemistry of spices by Parthasarathy VA, Chempakam B, Zachariah TJ. CAB International Oxford, UK: 2008. P.70-96.

4. Leung AY, Foster S. Encyclopedia of common natural ingredients used in food, drug and cosmetics. $2^{\text {nd }}$ ed. John Wiley and Sons, Inc., New York; 1996.

5. Govindarajan VS. GingerChemistry, Technology and Quality Evaluation Part 2. Crit Rev Food Sci Nut. 1982;17(1):189-258.

6. The Wealth of India, Raw materials and cumulative indexes, CSIR, New Delhi Reprinted. 2009;6:89-99.

7. Pieters L, Vlietinck AJ. Bioguided isolation of pharmacologically active plant components, still a valuable strategy for the finding of new lead compounds. $J$ Ethnopharmacol. 2005;100(1-2):57-60.

8. Balunas MJ, Kinghorn AD. Drug discovery from medicinal plants. Life Sciences 2005:78(5):431-41

9. Purseglove JW, Brown EG, Green CL, Robbins SRJ. Spices, Longman, London, England. 1981;1:46-59.

10. Lawrence BM. Ginger oil in progress in Essential oils. Perfumer and Flavorist. 2000;25(5):46-57.

11. Mollenbeck S, Konig T, Schreir P, Schwab W, Rajaonarivony J, Ranarivelo L. Chemical composition and analysis of enantiomers of essentials from Madagascar. Flavour Fragance J. 1997;12(2):63-9.

12. Bartley JP, Foley P. Supercritical fluid extraction of Australian grown ginger (Zingiber officinale Roscoe). J Sci Food Agric. 1994;66(3):365-71.

13. Variyar PS, Gholap AS, Thomas P. Effect of gamma irradiation on the volatile constituents of fresh ginger (Zingiber officinale Roscoe) rhizome. Food Res Int 1997;30(1):41-3.

14. Nishimura O. Identification of the characteristic odorants in fresh rhizomes of ginger (Zingiber officinale Roscoe) using aroma extract dilution analysis and modified multidimensional gas chromatography-mass spectrometry. J Agric Food Chem. 1995;43(11):2941-5

15. He WS, Li L, LiY, Guo SY, Guo BJ. GC-MS analyses of different solvent extracts of ginger. J Trop SubtropBot. 2001;9(2):154-158.

16. Sharma RK, Sarma TC, Lecereq PA. Essential oils of Zingiber officinale Roscoe from Northeast India. J Essential Oil Bearing Plants. 2002;5(2):71-6.

17. Martins AP, Salgueiro L, Goncalves MJ, Proenca da sCunha A, Vila R, Canigueral S. Essential oil composition and antimicrobial activity of three zingiberaceae from S. Tome e Principe. Planta Med. 2001;67(6):580-4.

18. Mahady GB. Ginger (Zingiber officinale Roscoe) and gingerols inhibit the growth of Cag A+ strains of Helicobacter Pylori. Anticancer Res. 2003;23(0):3699-702

19. Jagetia GC. Influence of ginger rhizome (Zingiber officinale Roscoe) on survival, glutathione and lipid peroxidation in mice after whole body exposure to gamma radiation. Radiat Res. 2003;160(5):584-92.

20. Sharma JN, Srivastava KC, Gan EK. Suppressive effects eugenol and ginger oil on arthritic rats. Pharmacol. 1994;49(5):314-8.

21. Nanasembat S, Lohasupthawee R. Antibacterial activity of crude ethanolic extracts and essential oils of spices against salmonellae and other enterobacteria. KMITL SciTech J 2005;5(3):527-38

22. Agarwal M, Walia S, Dhingra S, Khambay BPS. Insect growth inhibition, antifeedant and antifungal activity of compounds isolated/derived from Zingiber officinale Roscoe (ginger) rhizomes. Pest Manag Sci. 2001;57(3):289300.

23. Habsah M, Amran M, Mackeen MM, Lajis NH, Kikuzaki H, Nakatani N. Screening of Zingiberaceae extracts for antimicrobial and antioxidant activities. J Ethnopharmacol. 2000;72(3):403-10

24. Guptha S, Ravishankar S. A comparison of the antimicrobial activity of garlic, ginger, carrot and turmeric pastes against E.coli in laboratory buffer and ground beef. Foodborne Pathog Dis. 2005:2(4):330-40.

25. Prabuseenivasan $\mathrm{S}$, Jaykumar $\mathrm{M}$, Igancimuthu $\mathrm{S}$. In vitro antibacterial activity of some plant essential oils. BMC Compl Alter Med. 2006;6(1):39.

26. Wohlmuth H, Leach DN, Smith MK, Meyers SP. Gingerol content of diploid and tetraploid clones of ginger (Zingiber officinale Roscoe). J Agric Food Chem.
2005;53(14):5772-8

27. Akhila A, Tewari R. Chemistry of ginger: A review. Curr Res Med Arom Plants. 1984;6(3):143-56

28. Wohlmuth H, Smith MK, Brooks LO, Myer SP, Leach DN. Essential oil composition of diploid and tetraploid clones of ginger (Zingiber officinale Roscose) grown in Australia. J Agric Food Chem. 2006;54(4):1414-9.

29. Nogueira de MGA, Grespan R, Fonseca JP, Farinha TO, da Silva EL, Romero AL. Inhibitory effects of ginger (Zingiber officinale Roscoe) essential oil on leukocyte migration in vivo and in vitro. J Nat Med. 2011;65(1):241-6.

30. Sultan $M$, Bhatti HN, lqbal Z. Chemical analysis of essential oil of ginger (Zingiber officinale). Pakistan J Bio Sci. 2005;8(11):1576-8.

31. Yang Z, Yang W, Peng $Q$, He Q, Feng Y, Luo S, et al. Volatile phytochemical composition of rhizome of ginger after extraction by headspace solid-phase microextraction, petrol ether extraction and steam distillation extraction. Bangladesh J Pharmocol. 2009;4(2):136-43.

32. Vermin G, Parkanyi C. Ginger oil in spices, herb and edible fungi. G. Charalambour, editor. Amsterdam: Elsevier Sci Publ; 1994.

33. Pino JA, Marbot R, Rosado A, Batista A. Chemical composition of the essential oil of Zingiber officinale Roscoe L. from Cuba. J Essent Oil Res. 2004;16(3):186-8

34. El-Baroty G, Abd El Baky HH, Farag RS, Saleh MA. Characterization of antioxidant and antimicrobial compounds of cinnamon and ginger essential oils African J Biochem Res. 2010;4(6):167-74.

35. Asfaw N, Abegaz B. Chemical constituents of the Essential oils of Zingiber officinale Roscoe cultivated in Ethiopia. Ethiop J Sci. 1995;18:133-7.

36. Koroch A, Ranarivelo L, Behra OD, Juliani HR, Simon JE. Quality attributes of ginger and cinnamon essential oils from Madagascar. In: Janick J, Whipkey $A_{\text {, }}$ editors. Issues in new crops and new uses. Alexandria, VA: ASHS Press; 2007.

37. Sasidharan I, Menon N. Comparative chemical composition and antimicrobial activity of Fresh and dry ginger oils (Zingiber officinale Roscoe). International J Cur Pharm Res. 2010;2(4):40-3.

38. Padmakumari KP, Sreekumar MM, Sankarikutty B. Composition of volatile oil of ginger ( $Z$. officinale Roscoe) varieties from India. Indian Perfum. 2009;53(4):16-20

39. Rana VS, Verdeguer M, Blazquez MA. A comparative study on rhizome essential oils of three Zingiber species from Manipur. Indian Perfum. 2008:52(4):17-21.

40. Nigam MC, Nigam IC, Levi L, Handa KL. Essential oils and their constituents XXII. Detection of new trace compounds in oil of ginger. Can $\mathrm{J}$ Chem. $1964: 42(11) \cdot 2610-5$

41. Tiwari SK. Evaluation of ginger genotypes for yield and quality attributes under rain-fed and irrigated conditions. Annals Agric Res. 2003;24(3):512-5.

42. Bartley JP, Jacobs AL. Effects of drying on flavor compounds in Australiangrown ginger (Zingiber officinale). J Sci Food Agric. 2000;80(2):209-15.

43. Kelly CZ, Marcia OM, Adeemir JP, Angela AM. Extraction of ginger (Zingiber officinale Roscoe) oleoresin with CO2 and co-solvent: A study of the antioxidant action of the extracts. J Supercritical Fluids. 1995:24(1):57-76.

44. Bauer AW, Kirby WM, Sherris JC, Turck M. Antibiotic susceptibility testing by a standardized disc diffusion method. Am J Clin Path. 1966;45(4):493-6.

45. Daw ZY, El-Baroty GE, Mahmoud AE. Inhibition of Aspergillus parasiticus growth and aflatoxin production by some essential oils. Chem Mikrobiol Technol Lebensm. 1994;16(5/6):129-35.

46. Singh G, Kapoor IS, Singh P, de Heluani CS, de Lampasona MP, Catalan CA Chemistry, antioxidant and antimicrobial investigat ions on essential oil and oleoresins of Zingiber officinale. Food Chem Toxicol. 2008;46(10):3295-302

47. Felipe CF, Kamyla SF, André L, José NSB, Manoel AN, Marta MF. Alterations in behavior and memory induced by the essential oil of Zingiber officinale Roscoe (ginger) in mice are cholinergic-dependent. J Medicinal Plants Res. 2008;2(7):163-70.

48. Sasidharan SI, Venugopal VV, Menon AN. Essential oil composition of two unique ginger (Zingiber officinale Roscoe) cultivars from Sikkim. Nat Prod Res. 2012:26(19):1759-64.

49. Onyenekwe PC, Hashimoto S. The composition of the essential oil of dried Nigerian ginger (Zingiber officinale Roscoe). Europ Food Res Technol. 1999;209(6):407-10

50. Padalia RC, Verma RS, Sah AN, Karki N, Sundaresan V, Sakia D. Leaf and rhizome oil composition of Zingiber officinale Roscoe and their antibacterial and antioxidant activities. J Traditional Med. 2011;6(2):73-82.

51. Anwar F, Ali M, Hussain Al, Shahid M. Antioxidant and antimicrobial activities of essential oil and extracts of fennel (Foeniculum vulgare Mill.) seeds from Pakistan. Flav Frag J. 2009;24(4):170-6.

52. Baratta MT, Dorman HJD, Deans SG, Figueiredo AC, Barroso JG, Ruberto G. Antimicrobial and antioxidant properties of some commercial essential oils. Flav Frag J. 1998;13:235-44.

53. Farag RS, Daw ZY, Abo-Raya SH. Influence of some spice essential oils on Aspergillus parasiticus growth and production of aflatoxins in a synthetic medium J food Sci. 1989;54(1):74-6. 
PICTORIAL ABSTRACT

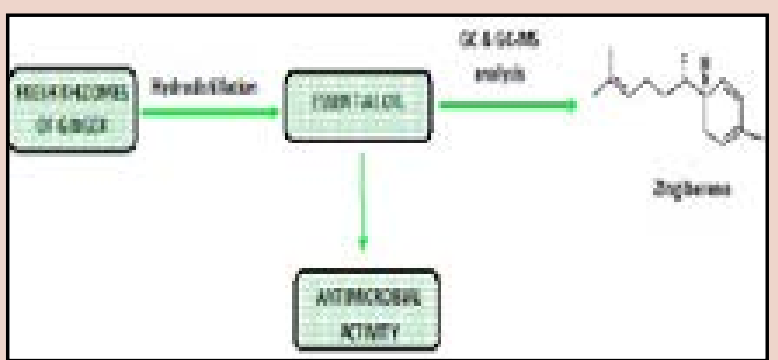

\section{SUMMARY}

- The essential oil was characterized by high percentage of sesquiterpenes (66.66\%), monoterpenes (17.28\%).

- The major component of the essential oil of ginger from Ghaziabad region was zingiberene $(46.71 \%)$

- Zingiberene is responsible for flavour and antimicrobial activity.

- The essential oil showed significant antimicrobial activity against pathogenic microorganisms.

\section{ABOUT AUTHOR}

Pradeep Kumar Sharma: Is an Associate Professor, Department of Pharmacy, R V Northland Institute, Greater Noida, G B Nagar, U.P., India. His research field focuses on Phytochemistry and biological activity testing of natural products. 